\title{
Efficient management of cough
}

\section{La prise en charge efficace de la toux}

$\mathrm{I}^{\mathrm{n}}$

$\mathrm{n}$ the present issue of the Canadian Respiratory Journal, Field et al (1) publish an interesting and provocative paper outlining the results of a trial of chronic cough management by allied health professionals, in this case Certified Respiratory Educators. This is an adaptation of the old technique of having patient care delivered by health care professionals other than physicians; it has long been a model in the Canadian North, on First Nations reservations and in the military. It is often touted as a way to control rampant medical costs, particularly in the United States. It seems almost self-evident that there are many things per-

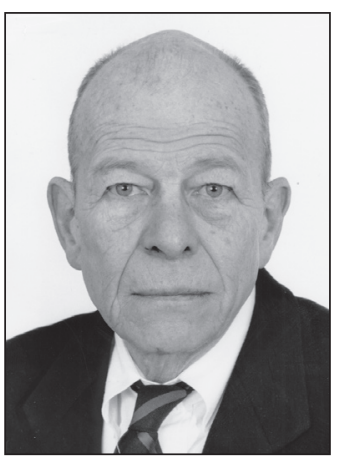

Nick R Anthonisen ans le présent numéro de la Revue canadienne $\bigcup_{\text {de pneumologie, Field et coll. (1) publient un }}$ article intéressant et provocateur sur les résultats d'un essai sur la prise en charge de la toux chronique par des professionnels paramédicaux, dans ce cas des Certified Respiratory Educators, un titre qui n'existe qu'en anglais. C'est une adaptation de la vieille technique qui consiste à dispenser les soins aux patients par d'autres professionnels de la santé que des médecins. Ce modèle existe depuis longtemps dans le Grand Nord canadien, dans les réserves des Premières nations et dans les forces armées. On le vante souvent comme un moyen de formed by physicians that do not require an MD degree, and because physicians are expensive and frequently in short supply, an efficient health care system would relieve them of these tasks. It also has the potential to improve patient care because allied health professionals are frequently able and willing to spend more time with patients and perhaps, to listen to them more attentively.

How does one set up a system of care by allied health professionals? I would argue that one must first settle on the scope of their practice. If a medical problem can be sharply defined, and an appropriate decision tree generated to solve it, management of the problem can theoretically be assigned to a nonphysician. However, patients are patients, often without sharply defined problems, and initial impressions regarding the problem and its solution may be erroneous. Thus, it is important for caregivers to be able to recognize difficulties, and having a medical background is important to operating such a system safely.

Field et al (1) postulated that chronic cough represents a problem that could be sharply defined, and that Certified Respiratory Educators could choose alternative methods of management correctly. They compared the outcomes of chronic cough management by physicians with those obtained by Certified Respiratory Educators, who are allied health professionals with special training and knowledge in respiratory diseases. Approximately 500 patients referred to their clinic for chronic cough were initially screened to eliminate those with abnormal chest $\mathrm{x}$-rays, known lung diseases or cancers, and "worrisome" symptoms such as weight loss. Interestingly, nearly one-half of the referrals had positive screens and were, therefore, not eligible as patients with chronic cough of unknown cause. The screen was apparently performed by physicians and checked by the educators. Of approximately 200 patients who were entered into the study, only five were subsequently found to have underlying lung disease - four with bronchiectasis, and one with interstitial lung disease.

Patients entering the study underwent spirometry and a quality of life questionnaire assessing the consequences of their cough, and were randomly assigned to either physician or contrôler les coûts de santé galopants, notamment aux ÉtatsUnis. Il semble évident que de nombreux gestes posés par les médecins ne nécessitent pas un diplôme en médecine, et comme les médecins coûtent cher et sont souvent en pénurie, un système de santé efficace les soulagerait de ces tâches. Ce modèle a également le potentiel d'améliorer les soins aux patients, car les professionnels paramédicaux sont souvent en mesure de passer plus de temps avec les patients, qu'ils ont envie de le faire et

Comment met-on sur pied un système de soins dispensés par des professionnels paramédicaux? J'avancerais qu'on commence par s'entendre sur la portée de leur pratique. Si un problème médical peut être clairement défini et qu'un arbre décisionnel pertinent peut être préparé pour le résoudre, sa prise en charge peut, en théorie, être confiée à un non-médecin. Cependant, les patients demeurent des patients, leurs problèmes sont souvent peu définis, et les premières impressions ainsi que les solutions peuvent être erronées. Il est donc important que les soignants puissent dépister les problèmes et possèdent une formation médicale pour exploiter un tel système en toute sécurité.

Field et coll. (1) ont postulé que la toux chronique constitue un problème pouvant être clairement défini et que les Certified Respiratory Educators pouvaient choisir des méthodes supplémentaires pour les prendre en charge correctement. Ils ont comparé les issues de prise en charge de la toux chronique par des médecins à celles obtenues par des Certified Respiratory Educators, des professionnels paramédicaux ayant une formation et des connaissances spéciales en maladies respiratoires. Environ 500 patients aiguillés vers leur clinique en raison d'une toux chronique ont d'abord subi un dépistage pour éliminer ceux qui avaient obtenu une radiographie thoracique anormale, qui avaient une maladie pulmonaire ou un cancer connu et qui présentaient des symptômes «inquiétants », comme une perte de poids. Fait intéressant, près de la moitié des aiguillages ont obtenu un dépistage positif et n'étaient donc pas admissibles parmi les patients ayant une toux chronique d'origine inconnue. Le dépistage était apparemment effectué par des médecins et vérifié par les éducateurs. Des environ 200 patients qu'ils les écoutent peut-être plus attentivement. 
educator care. The educators counselled the cigarette smokers and changed the medications of those on drugs that can cause cough. Based on their judgment, the physicians/educators decided whether the patients had postinfectious cough, rhinitis, asthma or gastroesphageal reflux, and treated them accordingly. At the end of the study, patients assigned to the educators did at least as well as those assigned to physicians in terms of symptom improvement. Indeed, educators' patients more commonly improved than did those of the physicians. Results were not brilliant in that approximately one-third of the patients did not improve after eight weeks of therapy, but as Field et al (1) point out, these were patients with extensive medical histories of futile efforts to control cough, in whom one would expect a low success rate. Certainly, I do no better.

Care processes for educators and physicians differed in that wait times for the educators were less than one-half that of physicians, and educators saw the patients more often than the physicians. Both of these are probably good, and the latter feature may have had something to do with the slightly greater success of the educators.

It would be hard to argue that educators managing these patients did not improve the efficiency of care of chronic cough. We should think about how similar care could be applied to other diseases, as is done in many asthma and COPD clinics already. The problem in applying this type of care often lies in funding - someone has to pay for the educators, because they cannot bill the health authority, and the authority may regard them as an added cost as opposed to a cost substitute. To the extent that the latter is truly the case, such an attitude is short-sighted, to put it mildly.

Nick R Anthonisen MD Editor-in-Chief, Canadian Respiratory Journal

\section{REFERENCE}

1. Field SK, Conley DP, Thawer AM, Leigh R, Cowie RL. Assessment and management of patients with chronic cough by Certified Respiratory Educators: A randomized controlled trial. Can Respir J 2009; $16(2): 49-54$. qui ont participé à l'étude, seulement cinq ont ensuite reçu un diagnostic de maladie pulmonaire sous-jacente, soit quatre cas de bronchiectasie et un cas de maladie pulmonaire interstitielle.

Les parents qui ont participé à l'étude ont subi une spirométrie et rempli un questionnaire sur leur qualité de vie pour évaluer les conséquences de leur toux, puis ils ont ensuite été attribués au hasard entre les soins par des médecins ou par des éducateurs. Les éducateurs ont conseillé les fumeurs et modifié les médicaments qui pouvaient provoquer la toux. D'après leur bon jugement, les médecins et les éducateurs ont décidé si les patients avaient une toux postinfectieuse, une rhinite, de l'asthme ou un reflux gastro-œsophagien, et ils les ont traités en conséquence. À la fin de l'étude, les patients du groupe des éducateurs ont obtenu des résultats au moins aussi bons que ceux du groupe des médecins pour ce qui est de l'amélioration des symptômes. En effet, l'état des patients des éducateurs s'est amélioré plus souvent que celui des médecins. Les résultats n'étaient pas phénoménaux, puisque l'état d'environ le tiers des patients ne s'est pas amélioré au bout de huit semaines de traitement. Toutefois, comme le soulignent Field et coll. (1), il s'agissait de patients aux longs antécédents médicaux d'échecs à contrôler leur toux, chez qui le taux de réussite pouvait être prévu. En tout cas, je ne peux faire mieux.

Les processus de soins entre les éducateurs et les médecins différaient, car les patients attendaient deux fois moins pour rencontrer un éducateur qu'un médecin, et ils voyaient les éducateurs plus souvent. Ces deux constats sont probablement positifs, et le deuxième explique peut-être en partie la réussite légèrement plus élevée des éducateurs.

Il serait difficile de prétendre que les éducateurs qui ont traité ces patients n'ont pas amélioré l'efficacité des soins de la toux chronique. On devrait réfléchir à la manière de dispenser des soins similaires à d'autres maladies, comme on le fait déjà dans de nombreuses cliniques sur l'asthme et les MPOC. Le problème quant à l'application de ce type de soins repose souvent sur le financement. Il faut que quelqu'un paie les éducateurs, qui ne peuvent facturer les autorités sanitaires, et celles-ci peuvent les percevoir comme un coût supplémentaire au lieu d'un remplacement des coûts. Dans la mesure où c'est le deuxième cas qui prévaut, une telle attitude est plutôt imprévoyante, pour employer un euphémisme.

Nick R Anthonisen MD Rédacteur en chef, Revue canadienne de pneumologie

\section{RÉFÉRENCE}

1. Field SK, Conley DP, Thawer AM, Leigh R, Cowie RL. Assessment and management of patients with chronic cough by Certified Respiratory Educators: A randomized controlled trial. Can Respir J 2009; 16(2):49-54. 


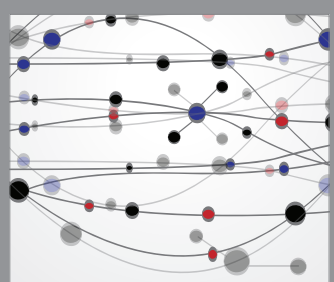

The Scientific World Journal
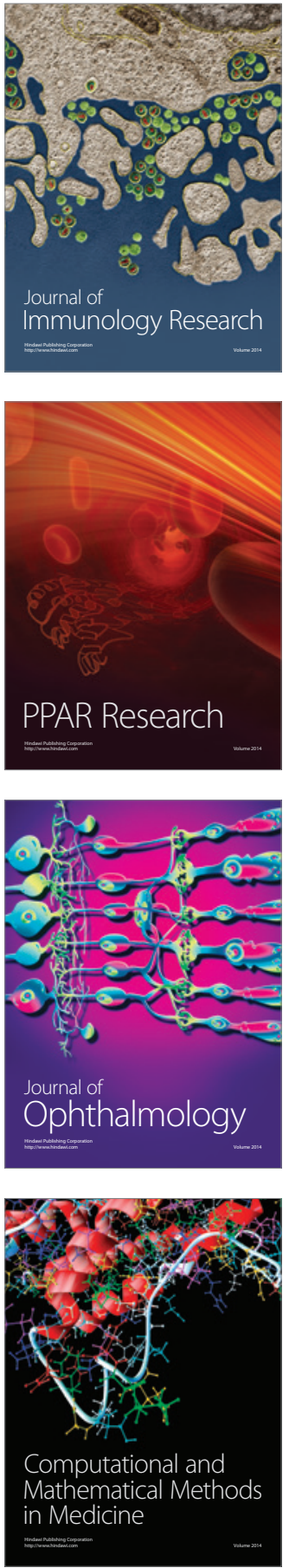

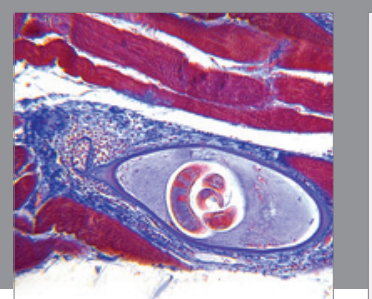

Gastroenterology Research and Practice

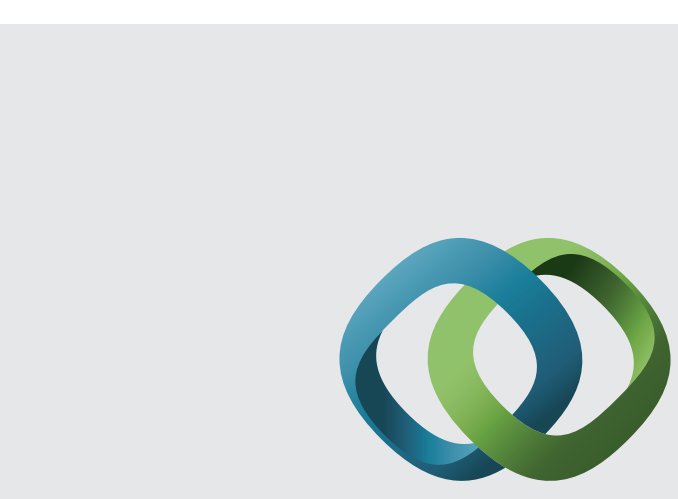

\section{Hindawi}

Submit your manuscripts at

http://www.hindawi.com
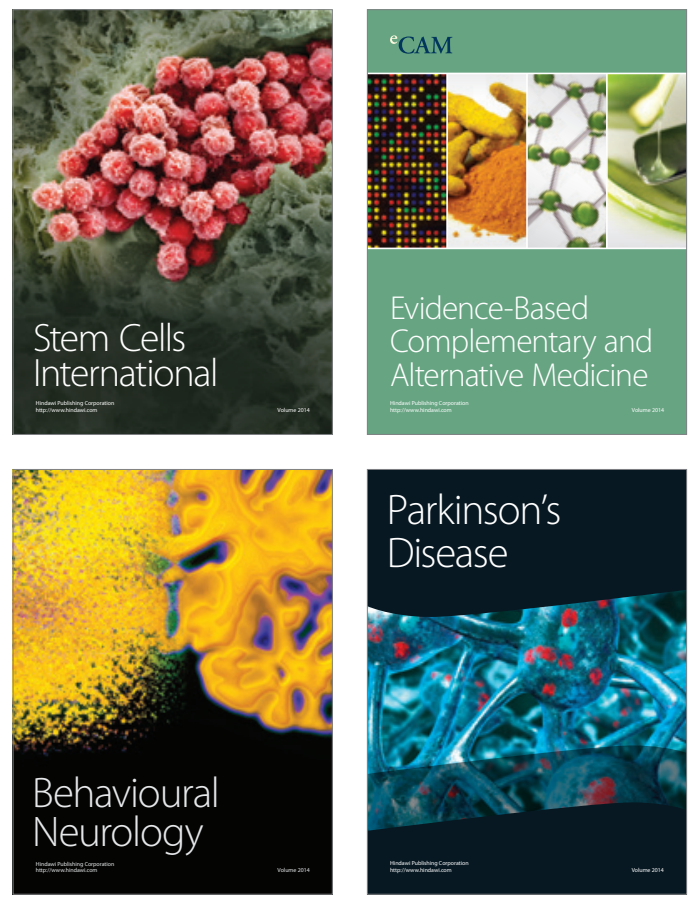
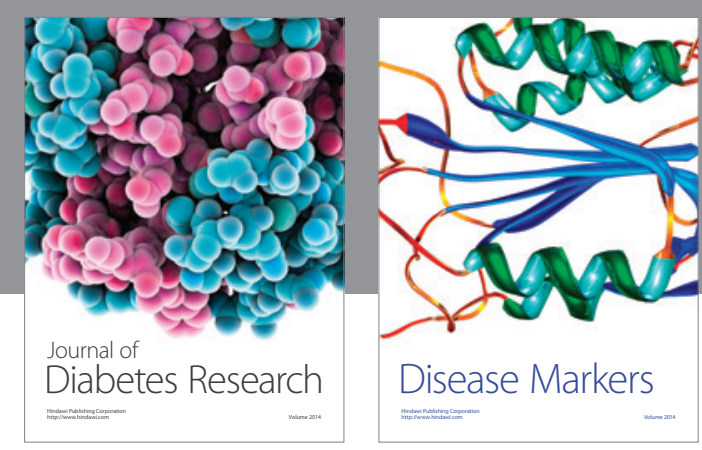

Disease Markers
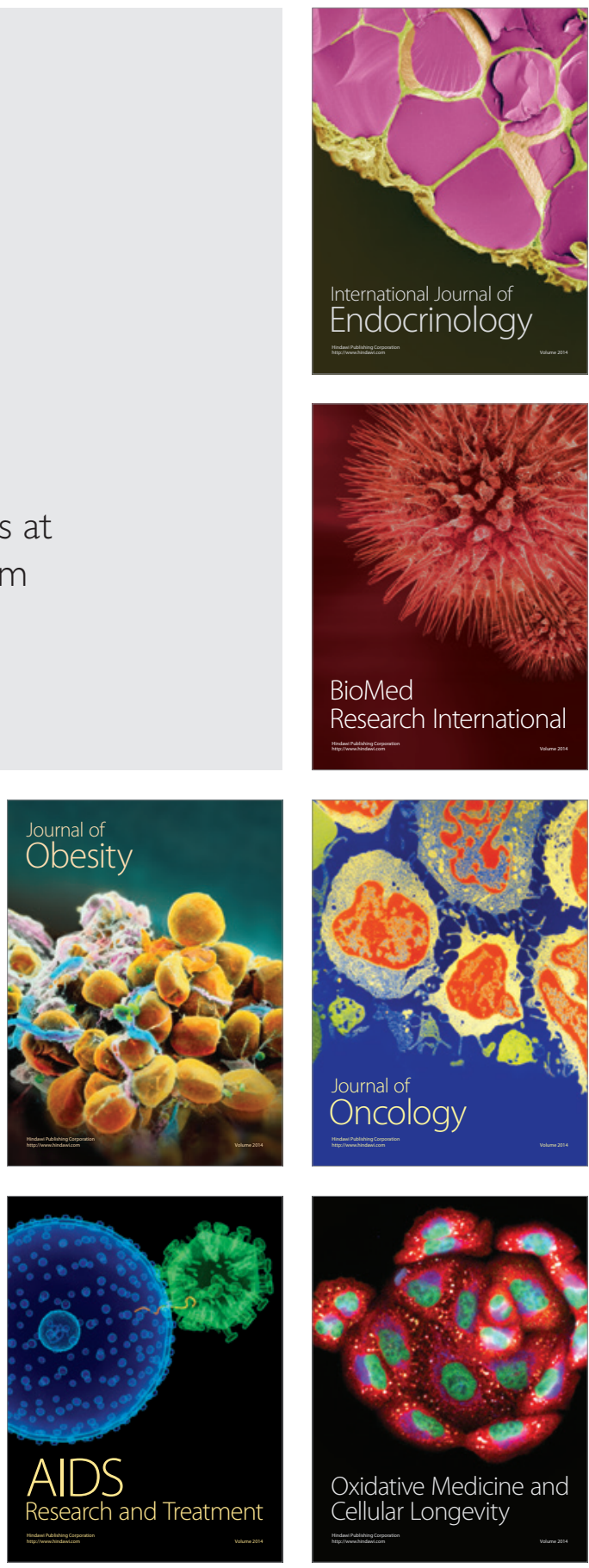